\title{
Can the silane heat treatment influence the bond durability between resin cements and a dental ceramic?
}

\author{
O tratamento térmico do silano pode influenciar na durabilidade \\ da adesão entre cimento e cerâmica dental?
}

\author{
Ronaldo Luís Almeida de CARVALHO' ${ }^{1}$ (D) 0000-0002-5383-7758 \\ Jean Soares MIRANDA ${ }^{1}$ iD 0000-0001-5379-0155 \\ Rodrigo Furtado de CARVALHO² ID 0000-0002-8271-8571 \\ Michelly Rocha DUARTE² iD 0000-0001-5169-0038 \\ Estevão Tomomitsu KIMPARA ${ }^{3}$ iD 0000-0003-0586-4644
}

Mutlu OZCAN ${ }^{4}$ (iD) 0000-0002-9623-6098

Fabíola Pessôa Pereira LEITE² iD 0000-0001-6316-5679

\section{ABSTRACT}

Objective: Evaluate the influence of silane heat treatment in bond durability between two resin cements and CAD/CAM feldspathic ceramic. Methods: 40 feldspathic ceramic blocks were obtained, and were duplicated in microhybrid composite. All ceramic blocks were etched with $10 \%$ hydrofluoric acid for $20 \mathrm{~s}$ and received application of silane agent. The blocks were randomized into eight groups $(n=5)$ according to the surface treatments and luting agents: P- Panavia F; PAg- Panavia F + Aging; HP- Heat Treatment + Panavia F; HPAg- Heat Treatment + Panavia F + Aging; R- RelyX ARC; Rag- RelyX ARC + Aging; HR- Heat Treatment + RelyX ARC; HRAg- Heat Treatment + RelyX ARC + Aging. The heat treatment was performed in furnace at $100{ }^{\circ} \mathrm{C}$ for 2 min. All blocks were cemented and cut to obtain samples with adhesive area of $1 \mathrm{~mm} 2$. Aging was performed with 10000 thermal cycles. The samples were subjected to microtensile bond strength test. Results: The three-way ANOVA test revealed a significant interaction between cement versus heat treatment $(p=0.001)$ and heat treatment versus thermal cycling $(p=0.001)$ indicating that there was a change in bond strength due to surface treatment and aging. Conclusion: Therefore, the heat treatment of the silane at $100^{\circ} \mathrm{C}$ for 2 minutes obtained higher values of bond strength between the resin cement and a feldspathic ceramic after aging.

Indexing terms: Aging. Ceramic. Tensile strength. Thermic treatment.

$\boldsymbol{\nabla} \nabla \boldsymbol{\nabla}$

1 Universidade Braz Cubas, Faculdade de Odontologia. Av. Francisco Rodrigues Filho, 1233, Vila Mogilar, 08773380, Mogi das Cruzes, SP, Brasil. Correspondence to: JS MIRANDA. E-mail: < jeansoares@msn.com>.

2 Universidade Federal de Juiz de Fora, Faculdade de Odontologia. Juiz de Fora, MG, Brasil.

${ }^{3}$ Universidade Estadual Paulista Júlio de Mesquita Filho, Instituto de Ciência e Tecnologia - Campus de São José dos Campos, Departamento de Materiais Odontológicos e Prótese. São José dos Campos, SP, Brasil.

${ }^{4}$ Division of Dental Biomateriais, University of Zurich. Plattenstrasse 11, 8001 Zürich, Switzerland.

$\boldsymbol{\nabla} \mathbf{v} \boldsymbol{v}$

How to cite this article

Carvalho RLA, Miranda JS, Carvalho RF, Duarte MR, Kimpara ET, Ozcan M, et al. Can the silane heat treatment influence the bond durability between resin cements and a dental ceramic?. RGO, Rev Gaúch Odontol. 2020;68:e20200001. http://dx.doi.org/10.1590/1981-8637202 0000012019-0002 


\section{RESUMO}

Objetivo: Avaliar a influência do tratamento térmico do silano na resistência de união entre dois cimentos resinosos e uma cerâmica feldspática CAD/CAM. Métodos: Quarenta blocos cerâmicos foram duplicados em resina micro-híbrida. Todas as cerâmicas foram condicionadas com ácido fluorídrico $10 \%$ por $20 \mathrm{~s}$ e receberam aplicação do silano. Os blocos foram randomizados em oito grupos $(n=5)$ : P-Panavia F; PAg-Panavia F + Envelhecimento; HP-Tratamento térmico + Panavia F; HPAg-Tratamento térmico + Panavia F + Envelhecimento; R-RelyX ARC; RAg-RelyX ARC; HR-Tratamento térmico + RelyX $A R C ; H R A g$ - Tratamento térmico + RelyX ARC + Envelhecimento. O tratamento térmico foi realizado em forno a $100{ }^{\circ} \mathrm{C}$ durante 2 min. Todos os blocos foram cimentados e cortados para obter amostras para microtração. Foram feitos 10000 ciclos térmicos. As amostras foram submetidas a teste de micro-tração. Resultados: O teste ANOVA revelou uma interação significativa entre cimento/tratamento térmico $(p=0,001)$ e tratamento térmico/ciclo térmico $(p=0,001)$. Conclusão: Dessa maneira, o tratamento térmico do silano a $100^{\circ} \mathrm{C}$ por 2 minutos foi capaz de aumentar a resistência de união entre o cimento resinoso e uma cerâmica feldspática mesmo após o envelhecimento.

Termos de indexação: Envelhecimento. Cerâmica. Resistência à tração. Tratamento térmico.

\section{INTRODUCTION}

Feldspathic ceramic is classified as an acid-sensitive ceramic; the surface can be treated with hydrofluoric acid, creating a topographic pattern that favors its micromechanical retention on restored teeth [1-3].

Prior to adhesive cementation, the use of chemical substances, such as a silane bond agent, is recommended. This is a monomer containing reactive organic group and monovalent hydrolysable group that form siloxane bonds between the inorganic phase of the ceramic and the organic phase of the applied resin cement [2-5]. The chemical bond promoted by the silane coupling agent is the main mechanism behind feldspathic ceramic adhesion to resin cements [6-7]. Furthermore, silane increases the surface energy of ceramic substrates and improves cement wetting, optimizing the microscopic interaction between cement and ceramic [6-7].

The implementation of heat treatment protocols prior to adhesive cementation has been suggested to improve the properties of the silane-coupling agent [78]. This pre-treatment helps eliminate water, alcohol, and other by-products from the ceramic surface, in addition to assisting in the completion of the condensation reaction between silica and silane, promoting the formation of a covalent bound at the ceramic-silane interface, consequently increasing the effectiveness and durability of the adhesion [7-8].

As the amount of metal-free restorations increases, and consequently the need for efficient adhesive cementation, this study had the intention of investigate the predictability of the cementation of ceramic restorations for the establishment of an effective cementation protocol.
Therefore, this study aimed to assess the influence of silane heat treatment on bond strength between resin cements with different chemical compositions and a feldspathic ceramic. The null hypothesis tested was that the silane heat treatment would not influence the bond strength of the resinous cement with the feldspathic ceramic.

\section{METHODS}

A total of 40 feldspathic ceramic blocks (12 $\times 7$ $x 5.5 \mathrm{~mm}$ ) were obtained from the cutting of VITA Mark II blocks (2L1.5, Vita Zahnfabrik; Säckingen, Germany) in a Buehler Isomet ${ }^{\circledR} 1000$ cutting device (Buehler; IL, USA). This was accomplished with a $12.7 \times 0.3-\mathrm{mm}$ diamond disc (Diamond Wafering Blade, Buehler; IL, USA) at low speed (250 rpm) under abundant irrigation and a 250-g load.

The cementing surface of each ceramic block was ground and polished in a polisher (PL02ET metallographic polisher, Precision; Brazil) using silicon carbide abrasive paper (3M, St. Paul, MN, USA) with the following grit: 600 , 800 , and 1200, under constant cooling. All blocks were then cleaned in an ultrasound apparatus (Cuba Ultrasound, Cristófoli; Campo Mourao, Brazil) with distilled water for 5 min and dried with compressed air.

Each ceramic block was molded with addition silicone (Elite H-D, Zhermack; Rovigo, Italy) inside a plastic container with the cementation surface facing down. After polymerization of the molding material, each ceramic block was removed from inside the mold and, after waiting one hour, a microhybrid composite resin (W3D MASTER, Brazil Wilcos Ind. e Com. Ltda.; RJ, Brazil) was applied in $2 \mathrm{~mm}$ increments. Each increment was photo-polymerized for $40 \mathrm{~s}$ (UltraLED-Ultradent ${ }^{\circledR}$; South Jordan, UT, USA) 
until completion of the mold, obtaining an analogue block of microhybrid composite resin $(12 \times 7 \times 5.5 \mathrm{~mm})$ for each ceramic block. All blocks (ceramic and composite resin) were then cleaned in an ultrasound apparatus with distilled water for $5 \mathrm{~min}$ and dried with compressed air. The ceramic blocks were duplicated to create a ceramic antagonist cementation interface. No tooth was used because the purpose of the study is the ceramic surface treatment, not the dentin surface.

All ceramic blocks were conditioned with 10\% hydrofluoric acid (Porcelain Conditioner - Dentsply; Brasil) for $20 \mathrm{~s}$, washed with water jets for $60 \mathrm{~s}$, cleaned in ultrasound with distilled water for $4 \mathrm{~min}$, and dried with air jets for $30 \mathrm{~s}$. A bond agent (Rely X Ceramic Primer - 3M ESPE; Seefeld, Germany) was applied in layers to the cementation surface of each ceramic block and rubbed for $30 \mathrm{~s}$. Following this, the ceramic surface was completely dried with air jet for $30 \mathrm{~s}$ to complete cementation, as recommended by the manufacturer. The blocks were then randomized into eight groups ( $n=5$ ) according to the surface treatments (table 1).

Table 1. Composition of the ceramic block groups.

\begin{tabular}{ll}
\hline Groups & \multicolumn{1}{c}{ Description } \\
\hline P & Panavia F \\
PAg & Panavia F + Aging \\
HP & Heat Treatment + Panavia F \\
HPAg & Heat Treatment + Panavia F + Aging \\
R & RelyX ARC \\
RAg & RelyX ARC + Aging \\
HR & Heat Treatment + RelyX ARC \\
HRAg & Heat Treatment + RelyX ARC + Aging \\
\hline
\end{tabular}

The ceramic blocks in the HP, HPAg, HR, and HRAg groups were placed in an F-1800 oven (EDG; SP, Brazil) at $100^{\circ} \mathrm{C}$ for 2 min to complete the heat treatment. After completion of the surface treatment, the ceramic blocks in groups P, PAg, HP, and HPAg were bonded to the composite resin blocks with Panavia $F$ resin cement (Kuraray Medical Inc.; Okayama, Japan), while the ceramic segments of Groups R, RAg, HR, and HRAg were bonded to the composite resin segments with RelyX ARC conventional resin cement (3M ESPE; Chicago, USA), prepared according to the manufacturers' recommendations. The ceramic-cement-resin assembly was placed in a surveyor (parallelometer) (Model B2, Bio-Art, dentistry equipment; Brazil) adapted for cementing with a cementation surface perpendicular to the application of a static vertical load of $750 \mathrm{~g}$ for $10 \mathrm{~min}$. After positioning the ceramic-cementresin assembly, the excess cement was removed with a Suprafill spatula (Model 01, Duflex; Rio de Janeiro, Brazil) and photo-polymerization was performed for $40 \mathrm{~s}$ on each margin of the adhesive line using a photo-curing unit (UltraLED- Ultradent ${ }^{\circledR}$; South Jordan, UT, USA).

The samples were stored in distilled water at $37{ }^{\circ} \mathrm{C}$ for 24 h. Shortly after, each ceramic-cement-composite resin assembly was embedded in chemically activated acrylic resin (Jet Type; Classic; São Paulo, Brazil) with the aid of a shaper and adapted to the Buehler Isomet ${ }^{\circledR} 1000$ cutting device (Buehler; IL, USA). The cuts were performed with a diamond disc (15.2 $\times 0.3 \mathrm{~mm})$ (Buehler; NY, USA) at low speed (250 rpm) under abundant irrigation and a 250-g load, from resin to ceramic, in order to obtain approximately $1 \mathrm{~mm}$ thick slices. The assembly was then rotated $90^{\circ}$ and subjected to further cutting to obtain micro samples.

Each ceramic-cement-composite resin assembly produced 18 rectangular sticks with a symmetric-quadrangular cross section, an adhesive area of $1 \pm 0.1 \mathrm{~mm}^{2}$, and $8 \mathrm{~mm}$ in length. The samples were submitted to aging only after the cuts.

The PAg, HPAg, Rag, and HRAg groups were submitted to 10,000 thermal cycles (Nova Ética Termocycler; São Paulo, SP, Brazil), with temperatures ranging from $5 \pm 1^{\circ} \mathrm{C}$ to $55 \pm 1^{\circ} \mathrm{C}$, and $30 \mathrm{~s}$ immersion in each bath.

The area of each sample (width and thickness) was measured with a digital pachymeter (Starret Indústria e Comércio Ltda.; SP, Brail) prior to performance of a mechanical microtensile test. The value of the area together with the load value for bond rupture were used to calculate the microtensile bond strength (in $\mathrm{MPa}$ ) using the following formula: Rt = F/A, where: Rt is the tensile strength; $F$, the applied force; and $A$, the area of the ceramic/cement/composite resin bond.

Following this, each sample was positioned in a universal testing machine (DL-1000 model, EMIC - Equipamentos e Sistemas Ltda.; São José dos Pinhais, PR, Brazil) with the bonding surface perpendicular to a 10-Kgf load cell. The samples were submitted to traction at a speed of $1 \mathrm{~mm} / \mathrm{min}$ until bond rupture. 
After the mechanical test, a stereomicroscope (Zeiss MC 80 DX Microscope) at 50 X magnification was used to examine the fractured surfaces of the samples and to determine the pattern at the failed ceramic/cement interface. Therefore, failure was classified as either adhesive (adhesive zone) or non-adhesive (cohesive in ceramic or resin composite).

The number of samples obtained after the cut ( $n$ available in table 3) was considered for statistical analysis. To evaluate the influence of the variables on bond strength, the samples were submitted to three-way ANOVA test and Tukey test by the SPSS 20.0 software.

\section{RESULTS}

During the cutting procedure, some pre-test failures occurred that were discarded prior to statistical analysis. Stereomicroscopic analysis revealed complete adhesive failures (100\%).

To evaluate the influence of the study variables on bond strength, the data obtained were submitted to analysis of variance (ANOVA) testing, after taking into consideration the normal distribution of the samples.

The three-way ANOVA test (table 2) revealed a significant interaction between cement versus heat treatment ( $p=0.001$ ) and heat treatment versus thermal cycling ( $p=0.001)$ indicating that there was a change in bond strength due to surface treatment and aging.

Based on the results of the ANOVA test, the data were submitted to the Tukey test (table 3 ), taking into consideration the groups demonstrating interaction of variables.
Table 2. Results of the three-way analysis of variance test.

\begin{tabular}{lc}
\hline Variables & $\boldsymbol{p}$-value \\
\hline Resin Cement & 0.004 \\
Heat treatment & 0.000 \\
Thermal cycling & 0.000 \\
Cement x Heat Treatment & 0.001 \\
Cement x Thermal Cycling & 0.125 \\
Heat Treatment x Thermal Cycling & 0.001 \\
Cement x Heat Treatment x Thermal Cycling & 0.694 \\
\hline
\end{tabular}

In the analysis of groups without aging, the highest value of bond strength was recorded in the Panavia resin cement group that received to silane heat treatment. The groups that presented lower bond strength were those with aging that did not receive silane heat treatment, independent of the type of resin cement (Panavia or RelyX ARC).

\section{DISCUSSION}

During the adhesive cementation of a ceramic restoration, several factors may influence adhesion to the dental structure $[7,9]$. After cementation, two interfaces are obtained, one between the resin cement and ceramic restoration and another between the resin cement and the tooth $[7,9]$. In this study, the bond strength of the interface formed between the ceramic and resin cement was evaluated using the microtensile bond strength test. This test was selected due to its improved reliability in dental tissues and ceramic adhesion tests compared with other methods [9]. In addition, it also allows the evaluation of numerous specimens with small adhesive surface areas

Table 3. Results of statistical analysis.

\begin{tabular}{|c|c|c|c|c|c|c|}
\hline \multicolumn{7}{|c|}{ Bond Strength (MPa) } \\
\hline \multirow{2}{*}{ Groups } & \multicolumn{3}{|c|}{ Non-Aged } & \multicolumn{3}{|c|}{ Aged } \\
\hline & Mean & $S D^{*}$ & $\mathrm{n}$ & Mean & $S D^{*}$ & $\mathrm{n}$ \\
\hline$P$ & 26.00 & $8.73 \mathrm{Ba}$ & 88 & 11.65 & $3.87 \mathrm{Bb}$ & 87 \\
\hline $\mathrm{HP}$ & 33.39 & $10.19 \mathrm{Aa}$ & 89 & 29.36 & $8.53 \mathrm{Aa}$ & 88 \\
\hline$R$ & 25.06 & $7.65 \mathrm{Ba}$ & 89 & 15.16 & $4.69 \mathrm{Bb}$ & 90 \\
\hline$H R$ & 23.84 & 7.16 Ba & 89 & 22.41 & $6.69 \mathrm{Ca}$ & 87 \\
\hline
\end{tabular}

Note: *Uppercase letters represent statistical differences in the vertical (column) and lower case letters represent statistical differences horizontally (rows). 
( $\pm 1 \mathrm{~mm}^{2}$ ), obtained from the adherence of small ceramic and resin blocks, facilitating the accurate assessment of the bonding between different substrates [11-12].

The results of this study showed a significantly positive effect of silane heat treatment on bond strength supporting previously published data [7, 13-14], which was capable to increase the bond strength, so the null hypothesis was denied. This happens because silane heat treatment enables the removal of water, alcohol, and other by-products from the ceramic surface. It also assists in the completion of the condensation reaction between silica and silane, promoting the formation of covalent bonds on the silane-ceramic interface that potentially generates a more durable adhesion [13].

In the presence of alcohol-based solvents, evaporation from the ceramic surface can affect the bond strength. After heating the silane, an interface with three different structures is observed, in contrast to a silane monolayer. The outer layer comprises small oligomers that are adsorbed on the glass and that can be removed by an organic solvent or water at ambient temperature. The second layer consists of similar oligomers connected by siloxane bridges hydrolysable by hot water. The crosslinking is more frequent and uniform in the region closer to the glass surface, forming a regular tridimensional network that is hydrolytically more stable. The latter is required to improve adhesion [13]. The removal of the outermost layer can promote a more effective adhesion of silane, leaving only the layer with the greatest stability [13].

When evaluating the influence of resin cement type in the groups that received silane heat treatment (HP, HPAg, HR, and HRAg), the groups cemented with Panavia displayed a higher mean bond strength than those cemented with RelyX ARC. A potential explanation for this may relate to the chemical composition of the Panavia $\mathrm{F}$ resin cement, specifically the presence of MDP. This monomer provides a stable chemical bond, resistant to hydrolytic degradation. However, the type of resin cement had no significant influence when comparing the groups. Similar results were found by Leite et al. who concluded that the conventional resin cement and one containing MDP would present similar bond strengths [15].

The effective adhesion of the samples in the present study may also be explained by the application of silane on the surface of ceramics conditioned with hydrofluoric acid, generating the dissociation of fluorosilicate salts. This occurs as a result of hydrolysis and absorption of silane on engraved surfaces. Another important factor is the ability of silane to promote a better surface wettability, creating a higher contact and infiltration of the bonding agent on the porous ceramic surface after conditioning with hydrofluoric acid [4].

To the best of our knowledge, there are no data available on the number of cycles that should be used to simulate the lifetime of a material in vivo; however, an estimate of 10,000 cycles, corresponding to 1 year of use, has been suggested [16]. The statistical difference in results between the thermocycled and non-thermocycled groups suggests that cement adhesion is significantly influenced by aging. This has also been observed in several previous studies in which ceramics are thermocycled, even when a loss of some specimens has occurred during this process $[9,17-18]$.

The microtensile bond strength data should be analyzed in combination with the type of failure. Failure analysis revealed that all fractures occurred at the adhesive area. These results are consistent with the results in published literature that have demonstrated a higher incidence of adhesive or mixed fractures with the microtensile bond strength test compared with conventional tests of adhesive resistance, which present a higher incidence of cohesive fractures $[7,10,12]$.

Some authors have demonstrated an effective bond strength when only heat treatment of silane is performed [8, 13-14]. However, according to the results obtained in the present study, the heat treatment of silane at $100^{\circ} \mathrm{C}$ for $2 \mathrm{~min}$ is effective to maintain the bond strength after aging between resin cement and feldspathic ceramic when associated with prior treatment using 10\% hydrofluoric acid.

The relevance of this study was the positive effect of heat treatment of silane on the bond strength between a resin cement and a feldspathic ceramic, before and after aging. The heat treatment of silane is effective in of byproducts removal, and when combined with a resin cement with MDP, showed the highest bond strength values.

\section{CONCLUSION}

The heat treatment of silane at $100^{\circ} \mathrm{C}$ for 2 min was capable to increase the bond strength between 
resin cement and a feldspathic ceramic after aging when associated with prior treatment using 10\% hydrofluoric acid.

\section{Collaborators}

RLA CARVALHO, MR DUARTE and JS MIRANDA performed the experiments, wrote the draft of the manuscript. RLA CARVALHO analyzed the data and wrote the manuscript. RF CARVALHO reviewed critically the manuscript for important intellectual content. FPP LEITE and ET KIMPARA analyzed the data, M ÖZCAN designed the study, analyzed the data and wrote the manuscript. All authors discussed the results and commented on the manuscript at all stages. The manuscript read and approved by all the authors, and each author believes the manuscript represents honest work.

\section{REFERENCES}

1. Aida M, Hayakawa T, Mizukawa K. Adhesion of composite to porcelain with various surface conditions. J Prosthet Dent. 1995 May; 73:464-470

2. Queiroz JR, Benetti $P$, Ozcan M, de Oliveira LF, Della Bona A, Takahashi FE, Bottino MA. Surface characterization of feldspathic ceramic using ATR FT-IR and ellipsometry after various silanization protocols. Dent Mater. 2012;28:189-196. http://dx.doi.org/10.1016/j.dental.2011.10.009

3. Cabral G, Miranda JS, Sato TP, Penteado MM, Anami LC, de Melo RM, Bottino MA, Moura Jr. JR, Prats FS. Reabilitação estético funcional - conjugação de restaurações em resina direta, laminados ultrafinos e onlays cerâmicas. Prótese News. 2017;4(1):64-74

4. Brentel AS, Ozcan M, Valandro LF, Alarça LG, Amaral R, Bottino MA. Microtensile bond strength of a resin cement to feldpathic ceramic after different etching and silanization regimens in dry and aged conditions. Dent Mater. 2007;23:1323-1331. http://dx.doi.org/10.1016/j.dental.2006.11.011

5. Della Bona A. Topographic changes caused acid etching on the surface of different ceramics. Braz Oral Res. 2004;18:137-137.

6. Campos F, Almeida CS, Rippe MP, de Melo RM, Valandro LF, Bottino MA. Resin bonding to a hybrid ceramic: effects of surface treatments and aging. Oper Dent. 2016;41:171-8. http://dx.doi.org/10.2341/15-057-L

7. de Carvalho RF, Cotes C, Kimpara ET, Leite FP, Özcan M. Heat treatment of pre-hydrolyzed silane increases adhesion of phosphate monomer-based resin cement to glass ceramic.
Braz Dent J. 2015;26(1):44-49. https://doi.org/10.1590/01036440201300212

8. Fabianelli, S. Pollington, F. Papacchini, C. Goracci, A. Cantoro, M. Ferrari, R. van Noort, The effect of different surface treatments on bond strength between leucite reinforced feldspathic ceramic and composite resin. J Dent. 2010;38(1):39-43. https://doi.org/10.1016/j.jdent.2009.08. 010

9. Antunes MCF, Miranda JS, Carvalho RAL, Carvalho RF, Kimpara ET, Souza ROA, Leite FPP. Can low-fusing glass application affect the marginal misfit and bond strength of Y-TZP crowns? Braz oral res 2018;32:1-10.

10. de Carvalho RF, Martins ME, de Queiroz JR, Leite FPP, Ozcan $M$. Influence of silane heat treatment on bond strength of resin cement to a feldspathic ceramic. Dent Mater J. 2011;30:392387. https://doi.org/10.1590/1807-3107bor-2018.vol32. 0034

11. Abreu CW, Santos JB, Passos SP, Michida SM, Takahashi $\mathrm{FE}$, Bottino MA. The influence of cutting speed and cutting initiation location in specimen preparation for the microtensile bond strength test. J Adhes Dent. 2011;13:221-226. https:// doi.org/10.3290/j.jad.a21540

12. Della Bona A, Anusavice KJ, Shen C. Microtensile strength of composite bonded to hot-pressed ceramics. J Adhes Dent. 2000;2:305-313.

13. Hooshmand T, van Noort R, Keshvad A. Bond durability of the resin-bonded and silane treated ceramic surfasse. Dent Mater. 2002;18(2):179-188. https://doi.org/10.1016/s0109-5 641(01)00047-1

14. Moharamzadeh K, Hooshmand T, Keshvad A, Van Noort R. Fracture toughness of a ceramic-resin interface. Dent Mater. 2008;24:172-177.

15. Leite FPP, Kimpara ET, Valandro LF, Andreatta Filho OD, Lopes AG, Bottino MA. Resistência à microtração entre dois cimentos resinosos e uma cerâmica vítrea de di-silicato de lítio. Odonto. 2003;21:41-50.

16. Gale MS, Darvell BW. Thermal cycling procedures for laboratory testing of dental restorations. J Den. 1999;27(2):89-99. https://doi.org/10.1016/s0300-5712(98)00037-2

17. Özcan M, Bernasconi M. Adhesion to zirconia used for dental restorations: a systematic review and meta-analysis. J Adhes Dent. 2015;17(1):7-26. https://doi.org/10.3290/j.jad.a33525

18. Silva EA, Trindade FZ, Reskalla HN, Queiroz JR. Heat treatment following surface silanization in rebonded tribochemical silica-coated ceramic brackets: shear bond strength analysis. J Appl Oral Sci. 2013;21(4):335-340. https://doi.org/10.15 90/1678-775720130012

Received on: 14/1/2019

Final version resubmitted on: 31/3/2019

Approved on: 29/4/2019 